DOI https://doi.org/10.18551/rjoas.2021-01.07

\title{
THE QUALITY OF ENVIRONMENTAL AGENCY'S SERVICE OF SANITARY SECTOR AT SAMPANG REGENCY OF INDONESIA DURING YEAR 2019
}

\author{
Bustanol Husein Mohammad*, Maimuna Fifin, Erina Saputri \\ Faculty of Administrative Science, University of Madura, Indonesia \\ *E-mail: inong@unira.ac.id
}

\begin{abstract}
From the previous study, it was found that the quality of Environmental Agency's service at Sampang Regency has not been satisfactorily applied. Garbage cleaning on the side of road and by the river often worked long, irregular hours. In this study. the researcher used quality service theory introduced by Fitzsimmons (1994:190). There were five Determinants of service quality, such as:Reliability, Responsiveness, Assurance, Empathy, Tangibles. The type of research is qualitative with descriptive approach. It is a research that aims to describe the events and phenomena that occures in the field related to quality of Environmental Agency's service. The result of this study shows that the quality of Environmental Agency's service at Sampang Regency is not good yet.
\end{abstract}

\section{KEY WORDS}

Quality service, sanitary sector, public service, annual results.

Service is an activity or a benefit that one party can offer to another that is essentially intangible and does not result in the ownership of anything. (Kotler 1994). According to Hadipranata service is an additional activity outside of the main task (job description) given to customers and it could be felt as an appreciation. (Moelyono, 2004:47).

Public service is generally defined as all goods and services provided by the government. While Law Number 25 of 2009 defines public services as series or activities in order to fulfill service needs in accordance with statutory regulations for every citizenfor public goods and services (Alfisyahrin, 2017:14).

Both central and regional government are responsible for the implementation of public service. In this case, people can give their advice and critics for th implementation so its substance plays an important role in regulating and directing services to achieve some goals.

One of government's service is about sanitary program provided by environmental agency's service. Generally, environemntal pollution become a serious problem in almost all regions in Indonesia. One of the most causes of the pollution is garbages. One of the factor of the pollution is the increasing population that arises the volume of waste everyday.

This environmental problem becomes more complicated because the waste in form of plastic bag. It is not easily broken down. It will decompose for at least 20 years in the soil.

Based on the research conducted by Jenna R Jambeck from Georgia University in 2010, it was found that there was 275 million ton of plastic waste produced over the wolrdwide. While it was predicted that Indonesia produced 3.22 million tons of plastic waste that polluted the oceans. From this data, Indonesia is the country with the second largest amount of plastic waste pollution to the sea in the world after China. According to Greeneration's research, non-governmenal organization that has studied about the issue of waste for about 10 years, it was predicted that Indonesian's person produced on average 700 plastic bags per year. (source: https://www.cnbnindonesia.com/tag/sampah-plastik. Accessed onb16 october 2019).

The increasing population of Sampang Regency affects on the increasing of waste's volume whereas the cleaning process is still less effective. Among the fourth regency in Madura island, flood often happens in Sampang almost every year because of the waste.

Both government and the community are responsible for cleaning the garbage. It is regulated in article 8 paragraph 2 of Government Regulation Number 59 of 2017 concerning communication policies and increasing community participation in waste management. 
Local government officials as public servant must find a professional way to fulfill communities needs because the needs are their responsibility.

Optimal service is also needed to achieve good public services. Public service is an important aspect to fulfill the society's interest. In the scope of state administration, public service arise because of the public interest. One form of public service is cleaning service.

The environmental service of Sampang Regency is a government agency that manages the cleanliness and environment sector in Sampang regency. To achieve this goal, Environmental officer of Sampang Regency urges the employers to serve the community in best way.

Less supervising to employees' performance causes the waste problem has not been solved yet. They often ignore their responsibilities of cleaning the waste. One of the community in Graha Indah Residence 2 stated that garbage often piled up there, even the available containers can't accomodate it anymore. It's because the trash truck rarely come to their residence although they have paid for it.

Besides that, one of the community mentioned that the environmental officers threw away the garbage from any residence along the river in Kramat Street Number 2. As a result, the garbage polluted the surrounding and also spoiled the view around the river, especially during the dry season. Even though the government had provided a landfill located in Pajudan Street. The landfill was actually constructed for trash recycling but the Environmental officer has not utilized it as well as possible.

Another complaints about the unpleasant smell of garbage revealed by people lived along Wilis street. They stated the the smell was caused by unscrupulous officer who threw away in field, not in certain landfill.

Public service is a process of providing the demands of the community (Moenir, 2016: 16). Fred Luthans defines the process as any action which is performed by managemen to achtieve organizational objectives. The service referred in this study is related to series of management organizations. However, the process generally involves all the efforts made by person in order to achieve some goals.

Public service is defined as all service activies carried out by public service providers as an effort to fulfiil public needs and to implement provisions of law and regulations (Mahmudi, 2005:229).

While, it is mentioned in Law Number 25 of 2009 concerning public services as manifestation of the demands of the community in providing quality services that are effecient and effective (Lukman, 2013:16).

In providing public service, we should apply the principles of good public services as set out in Permenpan No. 63 in 2003 as follows:

1. Simplicity. Public service procedure should be straightforward, easy to understand and also easy to implement.

2. Clarity. The clarity includes:

a. Technical and administrative requirements of public services;

b. The responsibility in providing the service and in solving their complaints;

c. Details of public service fees and payment procedures:

- Certainty of time. The implementation of public services can be completed within a predetermined time;

- Accuracy. Public service products are accepted correctly by public;

- Security. Public service should give secure and legal certainty;

- Responsibilty. The stakeholder of public service is responsible for the implementation of service, also for solving some problems about it;

- The availability of facilities and infrastructures. A public office should have complete facilities and infrastructures to support its service;

- Ease of access. A public service's office should be easily accessible by community.

- Discipline. Service providers must be disciplined, polite and in friendly way. Besides that it should provide sincere service; 
- Convenience. Public service office should be arranged orderly and supported with any facilities, such as pasking park, toilets, mosque, etc.

Although the principles of good public services as set out in Permenpan No. 63 in 2003 is more operational than as stated in management concepts and theories but sometimes there is some bias in real practice. People often convey their complaints about the public service by mass media(Ratminto, 2017:4).

Basically, every activity that is carried out must have a goal to be achieved and should be oriented on good quality. Quality is basically an abstract word, used to assess the degree of adjustment to the requirement. Joseph $\mathrm{M}$. Juran defines quality as fitness for use means that a product or service must be able to meet what is expected by the society (Nasution, 2005:34).

The quality of service can be measured by using quality measurement intrument developed by Zeithaml et.al in Ratminto et.al (2017:1). There are ten Determinants of service quality, as follows:

1. Tangible. The word "tangible" refers to things that are physical. They can be items that are able to be touched, see, heard or smelled, such as: buildings, rooms, facilities and any other tools that are used to contribute to customer loyalty;

2. Reliability. Reliability involves consistency of performance and dependability. It means that the firm performs the service right the first time and it can honors its promises;

3. Responsiveness. Responsiveness concerns the willingness or readiness of employess to provide service;

4. Competence. Competence means profession of the required skills and knowledge to perform the srvice. It involves knowledge and skill of operational support personnel and research capabity of the organization;

5. Courtessy. Courtesy involves politeness, respect, consideration and friendliness of contact personnel including receptionist, telephone operators, etc;

6. Credibility. Credibilty involves trustworthiness, believability, and honesty. It involves having the customer's best interesr at heart. Contributing to credibility are company name, company reputation, and persona; characteristucs of the contact personnel;

7. Security. Security is the freedom from danger, risk or daoubt. It involves physical safety, financial security and confidentiality;

8. Access. Access involves approachability and ease of contact. It means the service is easily approachability in location, facility and information;

9. Communication. Communication means keeping customers informed in languange they can understand and listening to them. It may mean that the company has to adjust its languange for different costumers;

10. Understanding the customer. Understanding the customer involves making the effort to understand the customer's needs.

Moreover Fitzsimmons (1994:190) delivered five dimensions of service quality measurement as follows:

1. Reliability. Realibilty is the ability to perform the promised service both dependably and accurately with error free;

2. Responsiveness. Responsiveness includes the speed of throuhput and the ability of the service to respond promply to customer service request with minimal waiting and queuing time;

3. Assurance. The assurance dimension includes the following features, they are: competence to perform the service, politeness and respect for the customer, effective communication with the customer and assurance of timing service;

4. Empathy. Empathy includes approachability, sensitivity and effort to understand the customer's needs;

5. Tangibles. The tangibles encompass the appearance of the company representatives, facilities, materials and equipment as well as communicaton materials that are able to support the service. 
The researchers used those five determinants proposed by Fitzsimmons to measure The Quality of Environmental Agency's Service of Sanitary Sector at Sampang Regency in 2019.

\section{METHODS OF RESEARCH}

This is qualitative descriptive research, aimed to provide an accurate description of an event and the importance a subject applies to the event at the present time.

According to Moleong (2013:6) qualitative researc is a research that intends to understand the phenomenon of what is experienced by the subject of research, such as behavior, perception, motivation, action and so forth.

The researcher used qualitative descriptive method because he/she wanted to describe the situation objectively by oobservation, interview, field note and other documentation regarding the quality of environmental agency's service of sanitary sector.

Since this research wanted to measure the quality of Environmental Agency's service of sanitary sector at Sampang Regency, this research was conducted at Environmental Service Office on Barisan Indah Street Number 1 at Sampang Regency.

This research focused on public perception towards the quality of environmental agency's service of sanitary sector that discuss on the principles of reliability, assurance, responsive, tangibles and empathy.

\section{RESULTS AND DISCUSSION}

The theory used in analyzing the quality of Environmental Agency's service is the theory proposed by Fitzsimmons in Sedarmayanti (2007: 266). There are five determinants in this theory; reliability, responsiveness, assurance, emphaty and tangibles.

The quality of environmental agency's service of sanitary sector of Sampang regency at 2019 in term of reability determinant was considered good. It supported by accurate standard service as stated in Perda No 8 of 2012 about waste cleaning and recycling. The competent officers are also responsible for this service alhtough they do not have high tittle.

Based on the result of the interview, it was found that in term of responsiveness determinant, the quality of environmental agency's service has not applied well yet. The cleaning service officer respond too long to clean the waste around the housing. In this case environmental agency opposed that there was certain team to solve the waste problem.

Furthermore in term of assurance determinant, the quality of environmental agency's service of sanitary sector of Sampang regency at 2019 was not good because the officer could not ensure the timing service to clean the garbage.

Empathy includes approachability, sensitivity and effort to understand the customer's needs. The environmental agency's service of sanitary sector of Sampang regency at 2019 has good empathy. People stated that the sanitary officers are polite and able to give solution about the waste.

The environmental agency's service of sanitary sector of Sampang regency did not have good facilities to clean the garbage along the river. They still use custom tools, and sometimes they use that tool for different purpose, not for carrying the garbage.

\section{CONCLUSION}

Based on the result of research conducted in Environmental Agency of Sanitary Sector at Sampang Regency in 2019, it was found that the service of solving waste problem was not good in terms of responsiveness, assurance, and tangibles. While the samples of this research stated that the service had good reability and empathy determinant. Although the service was not good in some terms, Environmental Agency of Sanitary Sector at Sampang Regency should improve its performance for better service next time. 


\section{REFERENCES}

1. Alfisyahrin, Muhammad. Peningkatan Kualitas Pelayanan Publik di Indonesia. Yayasan Pustaka, Cetakan kedua, Jakarta: 2018.

2. Bungin Burhan. Penelitian Kualitatif. Kencana Prenada Media Group, Cetakan keenam, Jakarta: 2012.

3. Lukman, Mediya. Badan Layanan Umum: Dari Birokrasi Menuju Korporasi. Bumi Aksara, Cetakan Pertama, Jakarta: 2013.

4. Mahmudi. Manajemen Kinerja Sektor Publik. Yogyakarta: 2005.

5. Moleong, Lexy J. Metode Penelitian Kualitatif. Remaja Rosdakarya, Cetakan ketigapuluh satu, Bandung: 2013.

6. Moenir. Manajemen Pelayanan Umum Di Indonesia. Bumi Aksara, Cetakan kedua belas, Jakarta: 2016.

7. Moeljono, Djokosantoso. Budaya Korporasi and Keunggulan Korporasi. Gramedia, Cetakan kelima, Jakarta: 2006.

8. Nasution, MN. Manajemen Pelayanan Terpadu edisi kedua. Ghalia Indonesia, Jakarta: 2005.

9. Ratminto dkk. Pelayanan Prima. Gadjah Mada University Press, Cetakan pertama, Yogyakarta: 2017.

10. Saggaf, Said,dkk. Reformasi Pelayanan Publik di Negara Berkembang. CV. Sah Media Makassar: 2018.

11. Sedarmayanti. Good Governance (Kepemimpinan yang baik) and Good Corporate Governance (Tata Kelola Perusahaan Yang Baik). CV Mandar Maju, Bandung: 2007.

12. Sugiono. Metode Penelitian: Kuantitatif,Kualitatif, and R\&D. Alfabeta, Bandung: 2016.

13. Soehartono, Irawan. Metode Penelitian Sosial. Remaja Rosdakarya, Cetakan ketujuh, Bandung: 2008.

14. Sirajuddin dkk. Hukum Pelayanan Publik: Berbasis Partisipasi and Keterbukaan Informasi, Cetakan kedua, Malang: 2012. 